\title{
Feasibility of machine integrated point of care lung ultrasound automatic B-lines tool in the Corona-virus 2019 critical care unit
}

\author{
Gal Tsaban 1,2,3, Ori Galante ${ }^{1,3}$, Yaniv Almog ${ }^{1,3}$, Yuval Ullman ${ }^{1,3}$ and Lior Fuchs ${ }^{1,3^{*}}$
}

In the last decade, the use of point-of-care lung ultrasound (POC-LUS) has substantially increased and in some intensive care units has largely replaced the routine use of chest X-rays tests [1]. While POC-LUS is highly efficient, it requires expertise, and when wrongfully interpreted may badly influence the treating physician's decision-making. Due to the logistic and medical equipment limitations in quarantined zones in which COVID-19 patients are treated, the importance of POCLUS increased [2]. We aimed to assess the reliability of a newly designed POC-LUS machine-integrated tool for automatic-real-time bedside quantification of B-lines among critical COVID-19 patients.

We assessed all patients admitted to the COVID-19 intensive-care unit in Soroka University Medical Center (SUMC) in Beersheva between February 2, 2020, and June 23, 2020. POC-LUS was performed daily during the routine medical rounds using Venue $_{\mathrm{TM}}$ ultrasound machine, General Electric.

Intensive care specialists acquired data in the COVID19 ICU by placing the probe longitudinally in the intercostal space and prospectively recording for four seconds. The 4-second time-frame allowed the shortest acquisition time with high sensitivity to detect B-lines [3]. All clips were reviewed and blindly assessed for B-lines quantification by two experienced physician operators (GT, 5 years and LF, 9 years). Separately, post hoc automatic

*Correspondence: liorfuchs@gmail.com

${ }^{1}$ Medical Intensive Care Unit, Soroka University Medical Center, P.O.B 151, Beersheva, Israel

Full list of author information is available at the end of the article analyses were performed using the Venue $_{\mathrm{TM}}$ integrated auto-B-lines tool.

Venue $_{\mathrm{TM}}$-auto-B-lines tool provides a grade between zero to $\geq$ five B-lines, detected only as lines reaching the bottom of the screen. Since the estimation of $\geq 3$ B-lines in LUS screening of the lungs' independent zones is considered pathological [4], we also divided the B-lines score to "dry" ( $\leq 3$ B-lines) or "wet" ( $\geq 4$ B-lines).

Each clip was considered an independent observation point. We divided the B-lines assessment into three severity groups: (1) $\leq 2$ (non-pathologic), (2) 3-4, and (3) $\geq 5$ (severe-ARDS). To assess the agreement between the automatic and physician-assessed quantifications, we performed Cohen's-Kappa tests. A two-sided $p$-value $\leq 0.05$ was considered statistically significant. All analyses were performed using SPSS 26.0 (Armonk, NY, USA).

During the study, 153 clips were acquired from ten patients. All clips were interpretable and included in the analysis. Patients were primarily males $(90 \%)$, with a mean age of $61.0 \pm 8.0$ and a mean body mass index of $24.5 \pm 10.5$. The mean-p/f-ratio was $203.7 \pm 83.2$, and $70 \%$ of patients were mechanically ventilated.

When assessed by physician, 104 observations were classified as group 3, 33 as group 2, and 16 as group 1 . In automatic analysis, 18 observations were classified as group 1, 33 as group 2, and 102 as group 3. An example of automatic-POC-LUS assessment across the spectrum of SARS-CoV2-ARDS severity is illustrated in Fig. 1. The weighted Cohen's-Kappa for agreement between the automatic and physician quantifications was $0.734(95 \%$ CI 0.641, 0.826; $p<0.001)$. When divided into "dry" $(\leq 3$ original author(s) and the source, provide a link to the Creative Commons licence, and indicate if changes were made. The images or other third party material in this article are included in the article's Creative Commons licence, unless indicated otherwise in a credit line to the material. If material is not included in the article's Creative Commons licence and your intended use is not permitted by statutory regulation or exceeds the permitted use, you will need to obtain permission directly from the copyright holder. To view a copy of this licence, visit http://creativecommons.org/licenses/by/4.0/. The Creative Commons Public Domain Dedication waiver (http://creativeco mmons.org/publicdomain/zero/1.0/) applies to the data made available in this article, unless otherwise stated in a credit line to the data. 


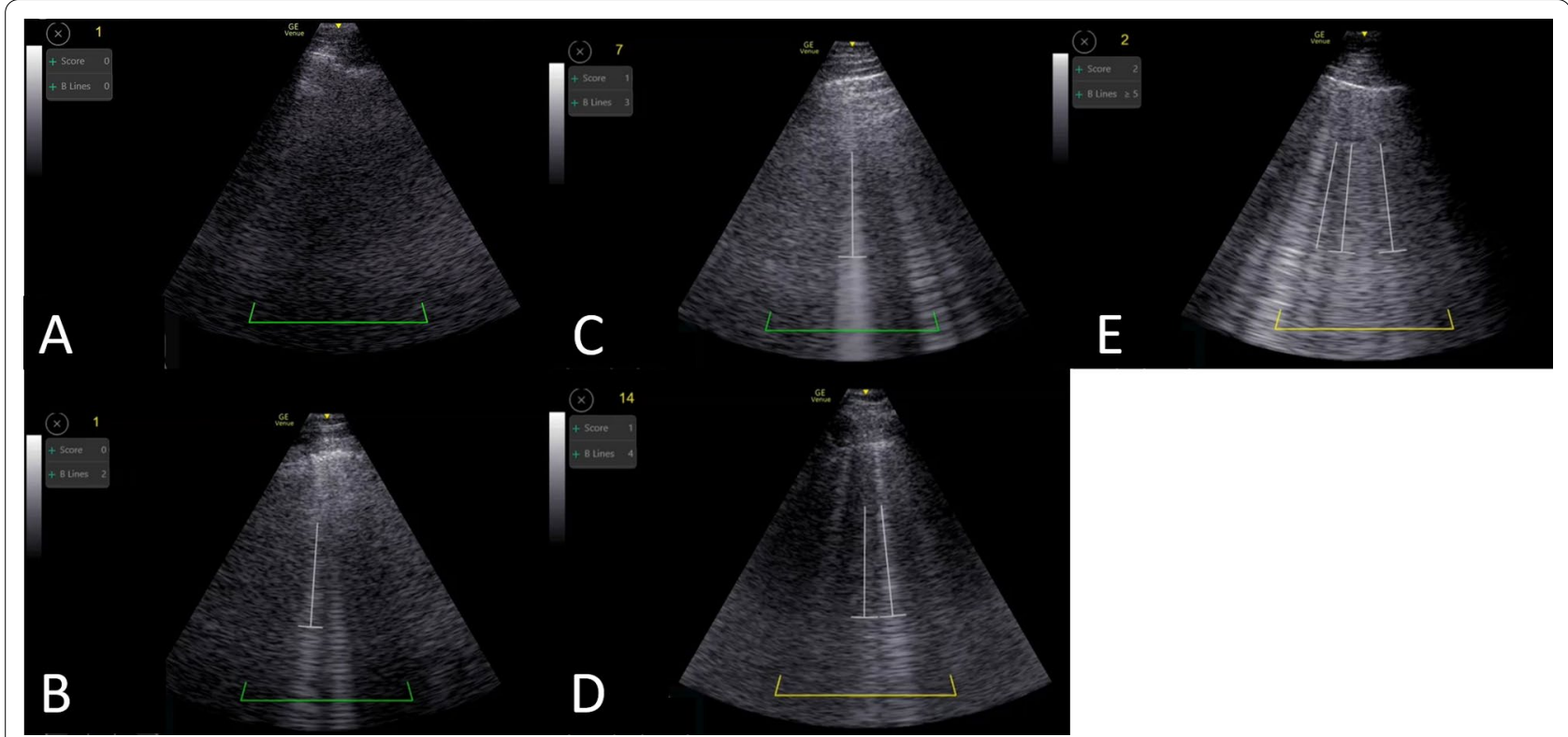

Fig. 1 Automatic POC-LUS assessment across the spectrum of ARDS severity. “Dry-lung": A 0 B-lines; B 2 B-lines; C 3 B-lines. "Wet-lung": D 4 B-lines; E 5 B-lines

B-lines) vs. "wet" ( $\geq 4$ B-lines), the weighted Cohen'sKappa was 0.822 (95\% CI 0.716, 0.928; $p<0.001$ ).

In conclusion, we found that the machine-integrated Venue $_{\mathrm{TM}^{-}}$-auto-B-lines tool is highly reliable among severe COVID-19 ICU patients. To our knowledge, this is the first study to validate a machine-integrated automatic-B-lines quantification tool with high reliability among COVID-19 patients. The small number of patients included in this feasibility trial should be acknowledged as a limitation; thus, further research to validate the results of this study is warranted. Previously, a non-integrated automatic B-lines detection application has shown good overall reliability while also stressing the difference in assessment reliability dependent on the operator experience [5]. The current study's results may help better interpret POC-LUS assessments performed by less-experienced operators and reduce interoperator variability. This tool may provide technological infrastructure for future telemedicine, even in non-experienced hands or for self-assessment by patients. The Venue $_{\mathrm{TM}^{-}}$-auto-B-lines tool may reduce the medical staff's exposure time and promote more accurate and standardized LUS assessment methods.

\section{Acknowledgements}

We thank the medical staff of the internal medicine division in SUMC and the nursing staff of the medical intensive care unit in SUMC for their valuable contribution to this study.
$O G, Y U$, and $Y A$ acquired the data. GT and LF are the guarantors of this paper and take responsibility for the work's integrity, from inception to publication of the article. All authors read and approved the manuscript.

\section{Funding}

This study was funded by General Electric. The sponsor was not involved in the study design, data interpretation and processing, data analysis, drafting of the manuscript or in the decision to publish the results.

\section{Availability of supporting data}

All supporting data are available upon request and pending the corresponding author's (LF) approval.

\section{Declarations}

\section{Ethical approval and consent to participate}

The study was approved by the SUMC institutional review board (\#2020-005017). As this was a retrospective analysis of existing data, participants were not required to supply informed consent.

\section{Consent for publication}

All authors have read and reviewed the manuscript and consent to the publication of the manuscript.

\section{Competing interests}

LF serves as a medical consulter for General Electric

\section{Author details}

${ }^{1}$ Medical Intensive Care Unit, Soroka University Medical Center, P.O.B 151, Beersheva, Israel. ${ }^{2}$ Department of Cardiology, Soroka University Medical Center, Beersheva, Israel. ${ }^{3}$ Faculty of Health Sciences, Ben Gurion University of the Negev, Beersheva, Israel.

Received: 17 July 2021 Accepted: 13 September 2021

Published online: 24 September 2021

\section{Authors' contributions}

GT and LF conceived and designed the study, performed post hoc sonographic analyses, and wrote the paper. GT performed statistical analyses. LF, 


\section{References}

1. Bouhemad B, Zhang M, Lu Q, Rouby JJ. Clinical review: bedside lung ultrasound in critical care practice. Crit Care. 2007;11:205.

2. Buonsenso D, Pata D, Chiaretti A. COVID-19 outbreak: less stethoscope, more ultrasound. Lancet Respir. 2020;8:e27.

3. Platz E, Pivetta E, Merz AA, Peck J, Rivero J, Cheng S. Impact of device selection and clip duration on lung ultrasound assessment in patients with heart failure. Am J Emerg Med. 2015;33:1552.

4. Dietrich CF, Mathis G, Blaivas M, Volpicelli G, Seibel A, Wastl D, et al. Lung B-line artefacts and their use. J Thorac Dis. 2016;8:1356-65.
5. Pičuljan A, Šustić M, Brumini G, Kuharić J, Šustić A. Reliability of B-line quantification by different-level observers and a software algorithm using point-of-care lung ultrasound. J Clin Monit Comput. 2020;34:1259-64. https://doi.org/10.1007/s10877-019-00440-7.

\section{Publisher's Note}

Springer Nature remains neutral with regard to jurisdictional claims in published maps and institutional affiliations.
Ready to submit your research? Choose BMC and benefit from:

- fast, convenient online submission

- thorough peer review by experienced researchers in your field

- rapid publication on acceptance

- support for research data, including large and complex data types

- gold Open Access which fosters wider collaboration and increased citations

- maximum visibility for your research: over 100M website views per year

At BMC, research is always in progress.

Learn more biomedcentral.com/submissions 